\title{
Associations between leptin gene polymorphism and some milk performance traits of cattle*
}

\author{
H. Kulig ${ }^{1}$ \\ Agricultural University of Szczecin, \\ Department of Genetics and Animal Breeding \\ Doktora Judyma 6, 71-466 Szczecin, Poland
}

(Received 13 September 2004; revised version 7 February 2005; accepted 18 March 2005)

\begin{abstract}
The aim of this study was to estimate the relations between the LEP/HphI, LEP/Sau3AI genotypes vs milk performance traits (yields of milk, protein, and fat, as well as protein and fat content) in 905 Polish Black-and-White cows, kept in Pomerania. The frequencies of $L E P / H p h \mathrm{I}$ genotypes were: $\mathrm{AA}, 0.582 ; \mathrm{AB}, 0.364 ; \mathrm{BB}, 0.054$. The frequencies of $L E P / S a u 3 \mathrm{AI}$ genotypes were: AA, 0.638; AB, 0.189; AC, 0.137; BB, 0.015; BC, 0.013, and CC, 0.008. Statistically significant $(\mathrm{P} \leq 0.01)$ relations between the leptin genotypes $(L E P / H p h \mathrm{I}, L E P / S a u 3 \mathrm{AI})$ and milk, protein and fat yields were found. These traits were significantly higher in the $L E P / H p h \mathrm{I} A \mathrm{~A}$ and $L E P /$ Sau3AI BB genotypes.
\end{abstract}

KEY WORDS: leptin gene, polymorphism, cows, milk traits

\section{INTRODUCTION}

Associations between QTLs or genetic markers and milk performance traits are being investigated on a large scale. Recently, studies have been broadened by including research on the leptin gene. Consequently, associations between certain genetic leptin variants and milk performance traits in cattle have been reported (Liefers et al., 2002; Zwierzchowski et al., 2002; Buchanan et al., 2003).

Leptin is a $16 \mathrm{kDa}$ polypeptide hormone, produced primarily by fat cells (Zhang et al., 1994; Halaas et al., 1995). It is involved in maintaining the energy balance by controlling food intake and energy expenditure (Halaas et al., 1995; Houseknecht and Portocarrero, 1998). In addition, leptin affects functioning of the endocrine system (Bornstein et al., 1997; Considine, 1997) and reproduction

\footnotetext{
* Supported by Agricultural Academy of Szczecin, BW/DB/13/99

${ }^{1}$ Corresponding author: e-mail: H.Kulig@biot.ar.szczecin.pl
} 
(Barash et al., 1996). The major site of leptin gene expression and leptin synthesis is the white adipose tissue (Zhang et al., 1994; Ji et al., 1998), smaller amounts of leptin are also synthesised in the placenta (Gong et al., 1996), and the mammary gland during lactation (Smith et al., 2002).

The presence of leptin was demonstrated in colostrum and/or milk of cattle (Bonnet et al., 2002), pigs (Estienne et al., 2000), sheep (McFadin et al., 2002), and in human milk (Houseknecht et al., 1997).

The aim of this study was to establish possible associations between leptin gene polymorphisms ( $L E P / H p h$ I and $L E P / S a u 3 \mathrm{AI})$ and some milk performance traits in Polish Black-and-White cows.

\section{MATERIAL AND METHODS}

The study involved a total of 905 Polish Black-and-White cows (the mean percentage of Holstein-Friesian blood was 68\%, range from 25 to 94\%). The cows were kept at 5 farms in Western Pomerania. All of the investigated animals were born between 1990 and 1998 and came from 182 sires. All of the cows in this study had completed their first lactation, 651 animals completed their first and second lactations, and 404 completed their first, second, and third lactations.

Polymorphism was analysed at two leptin gene sites. The first polymorphic site (LEP/HphI) is situated in the third (the second translated) exon of the gene (Haegeman et al., 2000) where the $\mathrm{C} / \mathrm{T}$ transition occurs. The other polymorphic site (LEP/Sau3AI) is situated within the intron sequence (Pomp et al., 1997).

The first fragment, $331 \mathrm{bp}$, of the leptin gene $(L E P / H p h \mathrm{I})$ was amplified using a pair of primers with the following nucleotide sequences: 5'-GGGAAGGGCAGAA AGATAG-3' and 5'-TGGCAGACTGTTGAGGATC-3' (Haegeman et al., 2000). Thermal cycling conditions included initial denaturation at $94^{\circ} \mathrm{C}$ for $10 \mathrm{~min}$, followed by 30 cycles of $94^{\circ} \mathrm{C}$ for $30 \mathrm{~s}, 55^{\circ} \mathrm{C}$ for $45 \mathrm{~s}$, and $72^{\circ} \mathrm{C}$ for $1 \mathrm{~min}$, followed by a final extension at $72^{\circ} \mathrm{C}$ for $10 \mathrm{~min}$. The PCR products were digested with $H p h$ I restriction nuclease.

Amplification of the next, $1820 \mathrm{bp}$, fragment of the leptin gene ( $L E P /$ Sau $3 \mathrm{AI})$ was carried out with a pair of the following primers: 5'-GTCACCAGGATCAATG ACAT-3' and 5'-AGCCCAGGAATGAAGTCCAA-3' (Pomp et al., 1997). The PCR conditions were as follows: $94^{\circ} \mathrm{C}$ for $8 \mathrm{~min}, 35$ cycles of $94^{\circ} \mathrm{C}-30 \mathrm{~s}, 55^{\circ} \mathrm{C}-45 \mathrm{~s}, 72^{\circ} \mathrm{C}-1 \mathrm{~min}$; the final step was at $72^{\circ} \mathrm{C}$ for $8 \mathrm{~min}$. The amplified fragments were digested with Sau3AI restriction nuclease.

The restriction fragments obtained were separated in $2 \%$ agarose gels with ethidium bromide and described using Vilber Lourmat software for photodocumentation of electrophoretic separation and image storage. 
All of the cows (905) were genotyped for the $L E P / H p h \mathrm{I}$ polymorphism and 861 for the $L E P /$ Sau3AI polymorphism.

The next stage involved analysis of associations between leptin genotypes and the following milk performance traits: milk yield $(\mathrm{kg})$, protein and fat yield $(\mathrm{kg})$, protein and fat content in milk (\%). Statistical analysis of milk performance traits in relation to $L E P / H p h$ I and $L E P / S a u 3 \mathrm{AI}$ genotypes was carried using the SAS/ STAT (1990) package. Differences between mean values of the traits were tested with Duncan's multiple range test. The following linear model was applied to all the traits analysed in the first lactation:

$$
Y_{i j k l m n}=\mu+S_{i}+R_{j}+O_{k}+(S R O)_{i j k}+G_{l}+h f_{m}+e_{i j k l m n}
$$

where:

$Y_{i j k l m n}$ - observed value

$\mu$ - trait mean

$S_{i}$ - herd effect $(i=1 \ldots 5)$

$R_{j}$ - year of birth effect $(j=1 \ldots 9)$

$O_{k}$ - sire effect $(k=1 \ldots 182$ for $L E P / H p h$ I and $1 \ldots 178$ for $L E P / S a u 3 \mathrm{AI})$

$(S R O)_{i j k}$ - herd $\mathrm{x}$ year of birth $\mathrm{x}$ sire interaction effect

$G_{l}$ - genotype effect ( $l=1,2,3$ for $L E P / H p h$ I and 1,2,3,4,5,6 for $\left.L E P / S a u 3 \mathrm{AI}\right)$

$h f_{m}$ - hf gene effect ( $m=1 \ldots 52$ for $L E P / H p h \mathrm{I}$ and $1 \ldots 48$ for $\left.L E P / S a u 3 \mathrm{AI}\right)$

$e_{i j k l m n}$ - error.

Analogical linear models were applied to the second and the third lactations.

\section{RESULTS}

The frequencies of $L E P / H p h \mathrm{I}$ genotypes and alleles were: $\mathrm{AA}, 0.582 ; \mathrm{AB}$, $0.364 ; \mathrm{BB}, 0.054 ; \mathrm{A}, 0.764 ; \mathrm{B}, 0.236$. The frequencies of $L E P /$ Sau $3 \mathrm{AI}$ genotypes and alleles were: AA, 0.638; AB, 0.189; AC, 0.137; BB, 0.015; BC, 0.013; and CC, 0.008; A, 0.801; B, 0.116; and C, 0.083 .

Mean values of the milk performance traits studied in three consecutive lactations in cows differing in their $L E P / H p h \mathrm{I}$ genotypes are given in Table 1. Analysis of the $L E P / H p h$ I genotype effects on milk yield during 305-day lactation showed the highest yield in the three consecutive lactations for the cows with the AA genotype. Differences in milk yield between cows of different $L E P / H p h \mathrm{I}$ genotypes were significant $(\mathrm{P} \leq 0.01)$ in lactation I and II. The AA cows produced significantly $(\mathrm{P} \leq 0.01)$ more milk in lactation I and II than the $\mathrm{AB}$ and $\mathrm{BB}$ cows, the difference between $\mathrm{AA}$ and $\mathrm{AB}$ averaging $189 \mathrm{~kg}$. The difference between AA and $\mathrm{BB}$ cows was somewhat higher $(194 \mathrm{~kg})$. In lactation II, the milk yield of 
TABLE 1

Means and standard deviation (SD) of studied traits in reference to $L E P / H p h$ I genotype

\begin{tabular}{|c|c|c|c|c|c|c|c|c|c|c|c|c|}
\hline \multirow{3}{*}{$\mathrm{L}$} & \multirow{3}{*}{$\begin{array}{l}\text { Geno- } \\
\text { type }\end{array}$} & \multirow{3}{*}{$\mathrm{n}$} & \multirow{2}{*}{\multicolumn{2}{|c|}{$\begin{array}{l}\text { Milk yield } \\
\text { kg }\end{array}$}} & \multicolumn{4}{|c|}{ Protein } & \multicolumn{4}{|c|}{ Fat } \\
\hline & & & & & \multicolumn{2}{|c|}{ yield, $\mathrm{kg}$} & \multicolumn{2}{|c|}{ content, $\%$} & \multicolumn{2}{|c|}{ yield, $\mathrm{kg}$} & \multicolumn{2}{|c|}{ content, $\%$} \\
\hline & & & mean & SD & mean & SD & mean & SD & mean & SD & mean & SD \\
\hline \multirow{4}{*}{ I } & $\mathrm{AA}$ & 524 & $5301^{\mathrm{AB}}$ & 1425 & $168.2^{\mathrm{AB}}$ & 48.1 & 3.17 & 0.19 & $220.6^{\mathrm{AB}}$ & 64.5 & 4.16 & 0.44 \\
\hline & $\mathrm{AB}$ & 331 & $5112^{\mathrm{A}}$ & 1351 & $160.9^{\mathrm{A}}$ & 45.5 & 3.13 & 0.20 & $210.2^{\mathrm{A}}$ & 59.4 & 4.11 & 0.44 \\
\hline & $\mathrm{BB}$ & 50 & $5107^{\mathrm{B}}$ & 1262 & $160.6^{\mathrm{B}}$ & 40.4 & 3.13 & 0.16 & $207.8^{\text {B }}$ & 57.7 & 4.07 & 0.41 \\
\hline & Total & 905 & 5221 & 1391 & 165.1 & 46.9 & 3.15 & 0.19 & 216.1 & 62.5 & 4.14 & 0.44 \\
\hline \multirow{4}{*}{ II } & AA & 355 & $5715^{\mathrm{A}}$ & 1486 & $185.8^{\mathrm{AB}}$ & 51.1 & 3.24 & 0.23 & $242.9^{\mathrm{AB}}$ & 73.8 & $4.26^{\mathrm{A}}$ & 0.54 \\
\hline & $\mathrm{AB}$ & 255 & 5636 & 1335 & $179.3^{\mathrm{A}}$ & 46.6 & 3.19 & 0.21 & $235.9^{\mathrm{AC}}$ & 69.4 & 4.14 & 0.57 \\
\hline & BB & 41 & $5539^{\mathrm{A}}$ & 1325 & $179.9^{\mathrm{B}}$ & 45.6 & 3.21 & 0.19 & $227.2^{\mathrm{BC}}$ & 60.0 & $4.01^{\mathrm{A}}$ & 0.45 \\
\hline & Total & 651 & 5673 & 1418 & 182.9 & 49.1 & 3.22 & 0.22 & 238.8 & 71.4 & 4.19 & 0.55 \\
\hline \multirow{4}{*}{ III } & AA & 215 & 6042 & 1584 & 196.6 & 52.7 & 3.20 & 0.20 & 258.7 & 78.8 & 4.19 & 0.56 \\
\hline & $\mathrm{AB}$ & 161 & 5944 & 1417 & 188.4 & 47.1 & 3.15 & 0.19 & 246.6 & 72.5 & 4.12 & 0.60 \\
\hline & $\mathrm{BB}$ & 28 & 5792 & 1680 & 183.2 & 57.8 & 3.14 & 0.19 & 231.7 & 70.1 & 4.00 & 0.33 \\
\hline & Total & 404 & 5986 & 1524 & 192.4 & 51.0 & 3.17 & 0.20 & 252.1 & 76.0 & 4.15 & 0.56 \\
\hline
\end{tabular}

L - lactation

$\mathrm{n}$ - number of animals recorded

$A, B, C$ - within columns means bearing the same superscript differ significantly at $\mathrm{P} \leq 0.01$

the AA cows was significantly higher than that of the BB cows only, the difference amounting to $176 \mathrm{~kg}$. In lactation III, despite a similar pattern of differences in the mean milk yield, the differences between genotypes were non-significant.

Similarly to milk yield, the AA cows showed the highest mean milk protein yield in lactations I, II, and III (Table 1). Significant differences $(\mathrm{P} \leq 0.01)$ were revealed between different genotypes in the first two lactations. The milk protein yield of the AA cows in lactation I was significantly higher, by 7.3 and $7.6 \mathrm{~kg}$, than that produced by the $\mathrm{AB}$ and $\mathrm{BB}$ cows, respectively. A similar pattern was observed in lactation II, although the differences were smaller.

Analysis of fat yield demonstrated the AA cows to produce milk of the highest fat yield in the three consecutive lactations. In lactation I and II, the AA cows produced milk with a significantly $(\mathrm{P} \leq 0.01)$ higher fat yield than that in either $\mathrm{AB}$ or BB cows; the differences in lactation I were 10.4 and $12.8 \mathrm{~kg}$, respectively. The corresponding differences in lactation II amounted to 7.0 and $14.7 \mathrm{~kg}$. In addition, the $\mathrm{AB}$ cows showed a significantly $(\mathrm{P} \leq 0.01)$ higher fat yield, compared with the $\mathrm{BB}$ cows in lactation II, the difference amounting to $8.7 \mathrm{~kg}$. In terms of milk per cent fat content, significant $(\mathrm{P} \leq 0.01)$ differences were observed between the $\mathrm{AA}$ and $\mathrm{BB}$ cows in lactation II, the milk fat content in the former being higher than that in the latter. 
Associations between $L E P /$ Sau $3 \mathrm{AI}$ genotypes and the milk performance traits analysed are described in Table 2 . Because of small sample size (1 individual), statistical analysis of lactation III disregards the CC cows.

TABLE 2

Means and standard deviation (SD) of studied traits in reference to $L E P / S a u 3$ AI genotype

\begin{tabular}{|c|c|c|c|c|c|c|c|c|c|c|c|c|}
\hline \multirow{3}{*}{$\mathrm{L}$} & \multirow{3}{*}{$\begin{array}{l}\text { Geno- } \\
\text { type }\end{array}$} & \multirow{3}{*}{$\mathrm{n}$} & \multirow{2}{*}{\multicolumn{2}{|c|}{ Milk yield, kg }} & \multicolumn{4}{|c|}{ Protein } & \multicolumn{4}{|c|}{ Fat } \\
\hline & & & & & \multicolumn{2}{|c|}{ yield, $\mathrm{kg}$} & \multicolumn{2}{|c|}{ content, $\%$} & \multicolumn{2}{|c|}{ yield, $\mathrm{kg}$} & \multicolumn{2}{|c|}{ content, $\%$} \\
\hline & & & mean & SD & mean & SD & mean & SD & mean & SD & mean & SD \\
\hline \multirow{7}{*}{ I } & AA & 552 & 5219 & 1444 & $165.3^{\mathrm{A}}$ & 48.4 & 3.16 & 0.20 & 216.1 & 64.5 & 4.14 & 0.45 \\
\hline & $\mathrm{AB}$ & 163 & 5106 & 1260 & $160.9^{\mathrm{B}}$ & 42.2 & 3.15 & 0.19 & 211.9 & 56.0 & 4.16 & 0.42 \\
\hline & $\mathrm{AC}$ & 116 & 5484 & 1375 & 173.9 & 46.6 & 3.17 & 0.20 & 227.4 & 64.8 & 4.14 & 0.43 \\
\hline & $\mathrm{BB}$ & 13 & 5823 & 1340 & $189.3^{\mathrm{ABC}}$ & 48.9 & 3.19 & 0.19 & $240.0^{\mathrm{A}}$ & 56.9 & 4.09 & 0.37 \\
\hline & $\mathrm{BC}$ & 11 & 5119 & 1150 & $157.9^{\mathrm{C}}$ & 41.2 & $3.07^{\mathrm{A}}$ & 0.12 & $206.0^{\mathrm{A}}$ & 46.5 & 4.06 & 0.52 \\
\hline & $\mathrm{CC}$ & 6 & 5391 & 2229 & 177.0 & 76.3 & $3.26^{\mathrm{A}}$ & 0.10 & 228.3 & 103.3 & 4.18 & 0.44 \\
\hline & Total & 861 & 5243 & 1405 & 166.0 & 47.3 & 3.16 & 0.19 & 217.1 & 63.1 & 4.14 & 0.44 \\
\hline \multirow{7}{*}{ Il } & AA & 392 & $5644^{\mathrm{A}}$ & 1363 & $182.2^{\mathrm{A}}$ & 48.3 & 3.22 & 0.22 & 240.2 & 69.9 & 4.23 & 0.56 \\
\hline & $\mathrm{AB}$ & 125 & $5575^{\mathrm{B}}$ & 1408 & $179.7^{\mathrm{B}}$ & 47.3 & 3.20 & 0.24 & 234.8 & 65.6 & 4.20 & 0.50 \\
\hline & $\mathrm{AC}$ & 85 & $6071^{\mathrm{C}}$ & 1578 & $195.9^{\mathrm{C}}$ & 52.9 & 3.23 & 0.21 & 252.0 & 83.4 & 4.13 & 0.60 \\
\hline & BB & 9 & $7409^{\mathrm{A}-\mathrm{E}}$ & 1415 & $238.8^{\mathrm{A}-\mathrm{E}}$ & 51.2 & 3.21 & 0.16 & 307.4 & 67.4 & 4.15 & 0.43 \\
\hline & $\mathrm{BC}$ & 8 & $5418^{\mathrm{D}}$ & 1357 & $171.6^{\mathrm{DF}}$ & 44.4 & 3.17 & 0.09 & 212.0 & 61.9 & 3.92 & 0.54 \\
\hline & $\mathrm{CC}$ & 5 & $6168^{\mathrm{E}}$ & 1324 & $206.2^{\mathrm{EF}}$ & 48.7 & 3.33 & 0.14 & 250.8 & 89.5 & 3.98 & 0.76 \\
\hline & Total & 624 & 5715 & 1422 & 184.4 & 49.3 & 3.22 & 0.22 & 241.4 & 71.5 & 4.20 & 0.55 \\
\hline \multirow{6}{*}{ III } & AA & 241 & $6005^{\mathrm{A}}$ & 1515 & $194.0^{\mathrm{A}}$ & 51.3 & 3.20 & 0.20 & 255.2 & 75.0 & 4.22 & 0.57 \\
\hline & $\mathrm{AB}$ & 86 & $5957^{\mathrm{B}}$ & 1572 & $191.2^{\mathrm{B}}$ & 49.0 & 3.16 & 0.18 & $247.3^{\mathrm{A}}$ & 74.6 & 4.07 & 0.51 \\
\hline & $\mathrm{AC}$ & 50 & $6033^{\mathrm{C}}$ & 1567 & $190.1^{\mathrm{C}}$ & 52.0 & 3.14 & 0.17 & $248.0^{\mathrm{B}}$ & 83.2 & 4.05 & 0.54 \\
\hline & BB & 5 & $8027^{\mathrm{A}-\mathrm{D}}$ & 1314 & $257.2^{\mathrm{A}-\mathrm{D}}$ & 43.4 & 3.21 & 0.19 & $33.8^{\mathrm{AB}}$ & 87.9 & 4.12 & 0.62 \\
\hline & $\mathrm{BC}$ & 6 & $4464^{\mathrm{D}}$ & 1739 & $183.0^{\mathrm{D}}$ & 77.1 & 2.99 & 0.19 & 252.8 & 119.2 & 4.09 & 0.87 \\
\hline & Total & 388 & 6003 & 1556 & 193.6 & 51.5 & 3.18 & 0.20 & 253.7 & 77.1 & 4.16 & 0.56 \\
\hline
\end{tabular}

L - lactation

$\mathrm{n}$ - number of animals recorded

$\mathrm{A}, \mathrm{B}, \mathrm{C}, \mathrm{D}, \mathrm{E}, \mathrm{F}$ - within columns means bearing the same superscript differ significantly at $\mathrm{P} \leq 0.01$

Analysis of the $L E P / S a u 3$ AI polymorphism effects on milk yield in three consecutive 305-day lactations showed the highest means for the cows with the BB genotype. The differences in milk yield were significant $(\mathrm{P} \leq 0.01)$ in lactation II and III. The largest difference was that between the BB and $\mathrm{BC}$ cows. In lactation II and III, the BC cows produced by 1991 and $3564 \mathrm{~kg}$ less milk, respectively, compared with the $\mathrm{BB}$ cows. In lactation I, the difference amounted to $704 \mathrm{~kg}$ and was not significant.

The highest milk protein yield was found for the cows with the BB genotype. The cows of different genotypes differed significantly $(\mathrm{P} \leq 0.01)$ in terms of their mean protein yield in each lactation. In lactation I, the BB cows produced significantly 
more protein than the $\mathrm{AA}, \mathrm{AB}$, and $\mathrm{BC}$ cows, the respective differences amounting to $24,28.4$, and $31.4 \mathrm{~kg}$. In lactation II, the BB cows showed a significantly higher protein yield, compared with all other genotypes, the largest difference of 67.2 $\mathrm{kg}$ being that between the $\mathrm{BB}$ and $\mathrm{BC}$ cows. In addition, the latter produced significantly less protein than the CC cows. Similarly, in lactation III, the protein yield differed significantly between the $\mathrm{BB}$ and the remaining genotypes. The largest difference $(74.2 \mathrm{~kg}$ ) was that between the $\mathrm{BB}$ and $\mathrm{BC}$ cows. Analysis of the per cent milk protein content showed the $\mathrm{CC}$ cows to produce milk of significantly higher (by $0.19 \%$ ) values of the trait, compared with the $\mathrm{BC}$ cows in lactation I. In lactation II, the $\mathrm{CC}$ and $\mathrm{BC}$ cows, too, showed the largest differences between their milk protein content, but the difference was not significant.

Similarly to milk and protein yields, the highest fat yield was that produced by the $\mathrm{BB}$ cows. The largest differences were those between the $\mathrm{BB}$ and $\mathrm{BC}$ cows in lactation I and II, the difference being significant in lactation I only $(34 \mathrm{~kg})$. In lactation III, the BB cows showed a significantly higher fat yield, compared with either the $\mathrm{AB}$ or $\mathrm{AC}$ cows, the respective differences amounting to 86.5 and $85.8 \mathrm{~kg}$.

\section{DISCUSSION}

Associations between milk performance traits and genetic markers are being investigated on a wide scale. Studies concerning associations between leptin gene polymorphism and performance traits of dairy cattle are, however, fairly scarce. Associations between LEP/HphI polymorphism and milk performance traits were followed in Holstein-Friesian cattle (Liefers et al., 2002). No significant differences in milk, protein, and fat yields as well as in per cent fat content between cows differing in genotypes were detected.

In contrast, associations between the $L E P / S a u 3 \mathrm{AI}$ polymorphism and milk performance traits were detected in Holstein-Friesian and Polish Black-andWhite cows. The Holstein-Friesian cow herd studied by Liefers et al. (2002) showed a significantly higher $(1.32 \mathrm{~kg})$ daily milk yield for the AB genotype cows, compared with the AA homozygote animals. In addition, the $\mathrm{AB}$ cows produced significantly more milk protein, compared with the AA group. The study involved three genotypes: AA, AB, and BB. On the other hand, the Polish Black-and-White cows analysed by Zwierzchowski et al. (2002) showed no associations between the $L E P / S a u 3 \mathrm{AI}$ genotypes and the per cent content of some milk components. The AC cows were, however, characterized by a significantly higher sum of fat, protein, lactose, and mineral per cent content as well as significantly higher fat and protein contents, compared with the AB genotype cows. The study did not involve 
$\mathrm{CC}$ cows (absent in the herd); neither did it include the $\mathrm{BB}$ and $\mathrm{BC}$ genotypes due to the low number of cows in both. Discrepancies between our findings and those of others can be explained by breed or population differences.

The results obtained in the present experiment show relations between leptin gene polymorphism and milk performance in Polish Black-and-White cows. The use of the LEP/HphI and LEP/SauBAI genotype appeared to be possible for milk, fat and protein yield improvement. Thus, in selection for improvement of these traits, cows with the $L E P / H p h$ I AA, LEP/Sau3AI BB genotype should be preferred. The presence of cows whose genotype contains allele $\mathrm{C}$, either homozygotes (CC) or in combination with allele A (AC heterozygotes), will be helpful in improving those traits.

Worth mentioning is the tremendous role of leptin in metabolism. Research involving humans and rodents showed leptin to inform the central nervous system about the magnitude of energy reserves and to control the metabolism of major tissues involved in energy storage and release (Halaas et al., 1995). It is suggested that leptin may inform the hypothalamus about energy reserves sufficient to support the energy demands of reproduction and to guarantee the success of pregnancy and lactation (Casabiell et al., 2001). In addition, the mammary gland is known as a leptin production site, leptin itself being detectable in milk (Houseknecht et al., 1997; McFadin et al., 2002; Smith et al., 2002). Moreover, significant positive correlations were reported between leptin level and fat content in edible commercial milk (Lage et al., 2002).

\section{CONCLUSIONS}

In this study, a relation between the LEP/HphI and LEP/Sau3AI genotypes and milk performance traits is shown. These polymorphisms might be markers for yields of milk and its components (protein and fat). If breeding programs are based upon $L E P / H p h \mathrm{I}$ and $L E P / S a u 3 \mathrm{AI}$ polymorphisms, a preference towards the $\mathrm{AA}$ and $\mathrm{BB}$ genotypes, respectively, may contribute to improving milk, protein, and fat yields.

It is necessary, however, to continue studies on associations between leptin genotypes and milk performance traits. Continuing these investigations will permit verification of the presented results before using them in dairy selection programmes. 


\section{REFERENCES}

Barash I.A., Cheung C.C., Weigle D.S., Ren H., Kabigting E.B., Kuijper J.L., Clifton D.K., Steiner R.A., 1996. Leptin is a metabolic signal to the reproductive system. Endocrinology 137, 31443147

Bonnet M., Delavaud C., Laud K., Gourdou I., Leroux C., Djiane J., Chilliard Y., 2002. Mammary leptin synthesis, milk leptin and their putative physiological roles. Reprod. Nutr. Develop. 42, 399-413

Bornstein S.R., Uhlmann K., Haidan A., Ehrhart-Bornstein M., Scherbaum W.A., 1997. Evidence for a novel peripheral action of leptin as a metabolic signal to the adrenal gland: leptin inhibits cortisol release directly. Diabetes 46, 1235-1238

Buchanan F.C., Van Kessel A.G., Waldner C., Christensen D.A., Laarveld B., Schmutz S.M., 2003. Hot topic: An association between a leptin single nucleotide polymorphism and milk and protein yield. J. Dairy Sci. 86, 3164-3166

Casabiell X., Piñeiro V., Vega F., De la Cruz L.F., Diéguez C., Casanueva F.F., 2001. Leptin, reproduction and sex steroids. Pituitary 4, 93-99

Considine R.V., 1997. Weight regulation, leptin and growth hormone. Hormone Res. 48, Suppl. 5, 116-121

Estienne M.J., Harper A.F., Barb C.R., Azain M.J., 2000. Concentrations of leptin serum and milk collected from lactating sows differing in body condition. Domest. Anim. Endocrinol. 19, 275-280

Gong D.-W., Bi S., Pratley R.E., Weintraub B.D., 1996. Genomic structure and promoter analysis of the human obese gene. J. Biol. Chem. 271, 3971-3974

Haegeman A., Van Zeveren A., Peelman L.J., 2000. New mutation in exon 2 of the bovine leptin gene. Anim. Genet. 31, 79

Halaas J.L., Gajiwala K.S., Maffei M., Cohen S.L., Chait B.T., Rabinowitz D., Lallone R.L., Burley S.K., Friedman J.M., 1995. Weight-reducing effects of the plasma protein encoded by the obese gene. Science 269, 543-546

Houseknecht K.L., McGuire M.K., Portocarrero C.P., McGuire M.A., Beerman K., 1997. Leptin is present in human milk and is related to maternal plasma leptin concentaration and adiposity. Biochem. Biophys. Res. Commun. 240, 742-747

Houseknecht K.L., Portocarrero C.P., 1998. Leptin and its receptors: regulators of whole-body energy homeostasis. Domest. Anim. Endocrinol. 15, 457-475

Ji S., Willis G.M., Scott R.R., Spurlock M.E., 1998. Partial cloning and expression of the bovine leptin gene. Anim. Biotechnol. 9, 1-14

Lage M., Baldelli R., Camiña J.P., Rodriguez-Garcia J., Peñalva A., Dieguez C., Casanueva F.F., 2002. Presence of bovine leptin in edible commercial milk and infant formula. J. Endocrinol. Invest. 25, 670-674

Liefers S.C., te Pas M.F., Veerkamp R.F., van der Lende T., 2002. Associations between leptin gene polymorphisms and production, live weight, energy balance, feed intake, and fertility in Holstein heifers. J. Dairy Sci. 85, 1633-1638

McFadin E.L., Morrison C.D., Buff P.R., Whitley N.C., Keisler D.H., 2002. Leptin concentrations in periparturient ewes and their subsequent offspring. J. Anim. Sci. 80, 738-43

Pomp D., Zou T., Clutter A.C., Barendse W., 1997. Rapid communication: Mapping of leptin to bovine chromosome 4 by linkage analysis of a PCR-based polymorphism. J. Anim. Sci. 75, 1427

SAS/STAT, 1990. Version 6, $4^{\text {th }}$ Edition. SAS Institute Inc., Cary, NC

Smith J.L., Sheffield L.G., 2002. Production and regulation of leptin in bovine mammary epithelial cells. Domest. Anim. Endocrinol. 22, 145-154 
Zhang Y., Proenca R., Maffei M., Barone M., Leopold L., Friedman J.M., 1994. Positional cloning of the mouse obese gene and its human homologue. Nature 372, 425-432

Zwierzchowski L., Krzyżewski J., Strzałkowska N., Siadkowska E., Ryniewicz Z., 2002. Effects of polymorphism of growth hormone (GH), Pit-1, and leptin (LEP) genes, cow's age, lactation stage and somatic cell count on milk yield and composition of Polish Black-and-White cows. Anim. Sci. Pap. Rep. 20, 213-227

\section{STRESZCZENIE}

Zależności między polimorfizmem w genie leptyny i niektórymi cechami użytkowości mlecznej bydła

Celem badań było ustalenie zależności między genotypami $L E P / H p h$ I $L E P / S a u 3 A I$ a cechami użytkowości mlecznej (wydajność mleka, białka i tłuszczu, zawartość białka i tłuszczu w mleku) u 905 krów rasy polskiej czarno-białej, na Pomorzu. Częstotliwość występowania genotypów LEP/ $H p h \mathrm{I}$ była następująca: AA - 0,582, AB - 0,364, BB - 0,054, genotypów $L E P / S a u 3 \mathrm{AI}$ wynosiła: AA $-0,638, \mathrm{AB}-0,189, \mathrm{AC}-0,137, \mathrm{BB}-0,015, \mathrm{BC}-0,013$, CC - 0,008. Wykazano istotne statystycznie $(\mathrm{P} \leq 0,01)$ zależności między genotypami $L E P / H p h \mathrm{I}$ oraz $L E P / S a u 3 \mathrm{AI}$ a wydajnością mleka, białka i tłuszczu badanych krów. Istotnie wyższe wartości tych cech stwierdzono u krów o genotypach $L E P / H p h$ I AA oraz LEP/Sau3AI BB. 